\title{
Kelekatan (Attachment) Anak Usia Dini di Suku Laut Kabupaten Wakatobi
}

\author{
La Hewi $^{1}{ }^{凶}$, Muh. Saleh ${ }^{2}$, Rizki Wahyuni ${ }^{3}$ \\ Pendidikan Islam Anak Usia Dini, Institut Agama Islam Negeri Kendari \\ DOI: $\underline{10.31004 / \text { obsesi.v4i1.346 }}$
}

\begin{abstract}
Abstrak
Penelitian ini bertujuan untuk mendeskripsikan kelekatan anak usia dini di suku laut yaitu desa Mola Selatan Kabupaten Wakatobi. Peneliti menggunakan pendekatan kualitatif untuk mendapatkan data yang komprehensif. Teknik pengumpulan data yang digunakan adalah wawancara, observasi dan studi dokumentasi. Teknik analisis data dalam penelitian ini menggunakan interaktif model dengan langkah-langkah analisis data yaitu reduksi data, penyajian data, penarikan kesimpulan dan verifikasi. Teknik pemeriksaan keabsahan data yang digunakan adalah teknik kredibilitas (derajat kepercayaan) yakni, triangulasi sumber. Hasil penelitian menunjukkan bahwa pertama, kelekatan anak usia dini di suku laut tergolong pada kelekatan yang kuat. kedua, kelekatan anak usia dini di suku laut desa Mola Selatan memiliki perbedaan antara di rumah dan di sekolah, yaitu di sekolah anak begitu lekat dengan figur dekatnya yaitu ibu, sedangkan di rumah kelekatan anak dengan ibunya bersifat tidak kuat.
\end{abstract}

Kata Kunci: kelekatan; anak usia dini; suku laut.

\begin{abstract}
This study aims to describe the attachment of early childhood in the sea tribe, namely the village of South Mola, Wakatobi Regency. Researchers used a qualitative approach to get comprehensive data. Data collection techniques used were intervieweds, observation and documentation study. The data analysis technique in this study uses an interactive model with the steps of data analysis namely data reduction, data presentation, drawing conclusions and verification. The data validity checking technique used is the credibility technique that is, member check triangulation. The results showed that first, attachment of early childhood in the sea tribes classified as strong attachment. second, the attachment of early childhood in the South Mola village tribe has a difference between at home and at school, namely at school the child is so attached to the close figure of the mother, while at home the attachment of the child to his mother is not strong.
\end{abstract}

Keywords: attachment; early childhood; sea tribe.

Copyright (c) 2019 La Hewi , Muh Saleh, Rizki Wahyuni

$\triangle$ Corresponding author :

Email Address : lahewih15@gmail.com (Jl. Sultan Qaimuddin No. 17 Baruga)

Received 26 November 2019, Accepted 16 December 2019, Published 17 December 2019 


\section{PENDAHULUAN}

Setiap individu menjalin hubungan dengan orang-orang di dekatnya, utamanya keluarga dan secara khusus kepada ibu atau bapak. Figur dekat ibu atau ayah terhadap anak akan menjalin hubungan yang menyenangkan antara kedua belah pihak, karena orang tua adalah tempat pertama bagi anak dalam menerima arahan dan bimbingan dalam bersikap dan berperilaku. Arahan dan bimbingan dari orang tua biasanya diberikan terhadap berdasarkan falsafah hidup yang orang tua anut, keyakinan agama, dan pengalaman hidup yang didapatkan oleh orang tua (Nauli, Karnadi, \& Meilani, 2019). Selanjutnya arahan dan bimbingan ini akan berkaitan dengan cara orang tua memberikan kasih sayang, peduli kepada anak, kedekatan dengan anak, memaksa anak untuk patuh, dan cara orang tua dalam mendisiplinkan anak yang terkadang keras dan tegas tetapi tanpa niat yang buruk. (Vega, Hapidin, \& Karnadi, 2019). Pengalaman hidup yang berbeda-beda antara orang tua yang satu dengan orang tua yang lain menyebabkan arahan dan bimbingan kepada anak berbeda antara anak yang satu dengan anak yang berasal dari keluarga lain.

Hubungan yang terjalin antara anak dengan figur dekatnya yaitu kedua orang tua utamanya ibu dilakukan dengan pemberian kasih sayang dan kenyamanan antar keduanya. Hubungan ini juga akan membentuk kelekatan antara anak dengan kedua orang tuanya utamanya figur ibu sejak anak dalam kandungan.(Robbiyah, Ekasari, \& Witarsa, 2018) Seorang anak akan tumbuh menjadi seorang manusia yang mandiri baik dalam hal emosi, dan berbuat sangatlah tergantung dan dipengaruhi oleh perlakuan dan hubungan orangtua dengan anak. Sebagaimana yang diungkapkan oleh Anapratiwi, Handayani dan Kurniawati dalam hasil penelitiannya menyimpulkan bahwa kelekatan anak dengan ibu memiliki hubungan dengan kemampuan sosialisasi anak usia 4-5 tahun. Lebih lanjut dijelaskan bahwa kelekatan aman memiliki hubungan yang positif pada kemampuan sosialisasi anak (Anapratiwi, D., Handayani, S.L.D., dan Kurniawati, 2013, p. 27). Sebaliknya kelekatan yang rendah akan berdampak buruk pada diri anak, Wahyuni dan Asra menyatakan bahwa anak yang memiliki kelekatan yang rendah dengan ibunya yang bekerja memiliki kecenderungan untuk menjadi pelaku atau korban bullying dibandingkan dengan anak yang memiliki kelekatan yang tinggi (Wahyuni, Sri dan Asra, 2014, p. 1).

Keluarga dalam menjalankan fungsinya sebagai tempat mengasuh dan memberi corak serta warna pada seorang anak. Pada masa bayi dan kanak-kanak, fungsi dan tanggung jawab utama sebuah keluarga adalah mengasuh, merawat, melindungi, membesarkan, dan melakukan proses sosialisasi. Izzah menyatakan bahwa gaya kelekatan kepada orang tua memiliki hubungan yang signifikan dengan harga diri anak pada saat remaja (Izzah, 2017, p. 137). Kelekatan dengan teman sebaya juga memiliki pengaruh terhadap diri anak. Illahi dan Akmal menyatakan bahwa kelekatan dengan teman sebaya memiliki hubungan yang positif dengan kecerdasan emosi pada remaja (Illahi, Sahrani P., dan Akmal, 2017, p. 171). Begitu juga dengan temuan penelitian yang dilakukan oleh Rahmah dan Prasetyaningrum menyatakan bahwa kelekatan dipengaruhi oleh kepribadian dalam hubungan pertemanan (Rahmah, Finda O., dan Prasetyaningrum, 2015, p. 167).

Relasi orang tua atau ibu kepada anak memiliki beberapa pola yang masing-masing pola memiliki karakteristik yang berbeda-beda antara satu pola hubungan dengan pola hubungan yang lain. Bowlby seorang psikolog dari inggris mengemukakan bahwa terdapat hubungan atau relasi antara anak dengan figur dekat, yang disebut dengan kelekatan (attachment) (Bowlby, 1984, p. 293). Anak yang memiliki kelekatan dengan ibu dan ayahnya akan memiliki kompetensi sosial yang baik (Purnama, Aulia Rika dan Wahyuni, 2017, p. 38).

Oates menyatakan bahwa attachment adalah ikatan emosional bahwa bayi berkembang dengan orangtua mereka dan pengasuh utama lainnya. Hubungan ini sangat penting untuk anak-anak kesejahteraan dan untuk mereka emosional dan pembangunan social (Oates, 2007, p. 1). Attachment adalah istilah yang digunakan untuk menggambarkan ikatan dari anak terhadap orang tua mereka atau pengasuh utama. Perilaku attachment yaitu perilaku yang gunakan anak-anak untuk mendapatkan perhatian, atau untuk tetap dekat 
dengan pengasuh mereka dalam situasi ketika mereka lelah, tidak enak badan atau takut (Scott, 2011). Ikatan attachment sangat penting untuk kesejahteraan anak dan sosio emosional dan perkembangan sosial anak. Penelitian yang dilakukan oleh Anapratiwi, Handayani dan Kurniawati tentang hubungan antara kelekatan anak pada ibu dengan kemampuan sosialisasi anak usia 4-5 tahun, membuat kesimpulan bahwa kelekatan anak dengan ibu memiliki hubungan dengan kemampuan sosialisasi anak usia 4-5 tahun. Kelekatan aman memiliki hubungan yang positif pada kemampuan sosialisasi anak sementara untuk kelekatan cemas menghindar tidak memiliki hubungan dengan kemampuan sosialisasi anak (Anapratiwi, D., Handayani, S.L.D., dan Kurniawati, 2013, p. 27).

Santoso dan Batubara melakukan studi tentang Kelekatan Antara Ibu dan Anak Usia Sekolah, membuat kesimpulan bahwa kelekatan antara ibu dan anak terbentuk dari interaksi kerjasama keduanya dalam menjalankan tugas-tugasnya di lingkungan sosialnya masingmasing (Santoso, Meilanny B., dan Batubara, 2017, p. 61). Begitu juga dengan studi yang dilakukan oleh Nurhayati tentang Hubungan Kelekatan Aman (Secure Attachment) Anak pada Orangtua dengan Kemandirian Anak Kelompok B, menemukan bahwa kelekatan yang aman memiliki hubungan yang positif dengan kemandirian anak usia 5-6 tahun (Nurhayati, 2015, p. 1).

Beberapa studi terdahulu menemukan bahwa kelekatan anak dengan orang tua atau ibu berpengaruh pada kemampuan anak dalam melakukan sesuatu atau kemampuan anak untuk berperilaku. Sehingga Attachment sebagai sebuah bentuk khusus dari hubungan emosional yang melibatkan hubungan yang saling menguntungkan antara anak dengan figur dekatnya (mutualisme), kenyamanan, keamanan dan kesenangan yang baik untuk individu dalam suatu hubungan. Perry menyatakan bahwa Attachment memiliki beberapa elemen kunci, antara lain pertama, Attachment adalah hubungan emosional abadi dengan orang tertentu, kedua Hubungan membawa keamanan, kenyamanan, menenangkan dan kesenangan, ketiga Kerugian atau ancaman sebagai akibat dari hilangnya orang tersebut membangkitkan tekanan lebih. Bentuk khusus dari hubungan adalah terbaik ditandai dengan hubungan ibu-anak (Perry, 2013). Weingarten dan Chisholm menyatakan bahwa Ibu atau pengasuh utama adalah tempat yang aman di mana bayi dapat mencari keamanan dan kenyamanan, berlindung dari ancaman dan marabahaya, dan basis yang aman untuk mengeksplorasi, dengan harapan bahwa ibu akan tersedia untuk melindungi kapan pun jika dibutuhkan oleh anak. attachment selektif terhadap figur tertentu, biasanya satu tokoh attachment primer yang biasanya ibu, namun beberapa attachment dengan orang tambahan sedikit yang umum, misalnya, ayah, kakak, atau pengasuh lainnya (Weingarten \& Chisholm, 2009). Sintesis dari kedua konsep attachment yang telah dipaparkan di atas yaitu hubungan emosional yang terjalin antara anak dengan dengan orang tua utamanya ibu. Hubungan ini membawa kenyamanan, keamanan dan menenangkan antara keduanya serta salah satu akan merasa kehilangan jika yang lain tidak berada di dekatnya.

Crain menjelaskan bahwa attachment memiliki tiga pola dasar yaitu pertama (securily attached infants), kedua (insecure-avoidant infants), dan ketiga (insecure-ambivalent infants), (Crain, 2007, p. 81-84) yaitu anak memiliki pola kelekatan dengan figur dekat atau ibunya yang berbeda-beda antara satu dengan yang lain. Ada anak yang merasa sangat membutuhkan kenyamanan dari ibunya dan tidak bisa berada jauh dari ibunya, ada pula anak yang tidak begitu membutuhkan rasa aman dari ibunya tetapi tetap membutuhkan ibunya, serta yang terakhir anak sangat lengket dengan ibunya dan akan marah ketika ibunya berada jauh darinya. Hanya ketika ibunya kembali datang, anak akan bersikap seolah-olah tidak membutuhkan ibunya. Hal ini disebabkan karena ibu tidak konsisten dalam merawat anaknya, kadang hangat dan kadang tidak begitu peduli kepada anaknya. Cenceng menyatakan bahwa kelekatan pada anak memiliki tiga pola yaitu kelekatan pola aman, kelekatan pola melawan dan kelekatan pola menghindar (Cenceng, 2015, p. 141). 
Upton mengemukakan klasifikasi kelekatan anak dengan figur dekat atau ibunya yang didasarkan pada perilaku anak selama berpisah dan bertemu kembali dengan figur dekatnya, yaitu pertama Anak-anak dengan kelekatan kuat, menggunakan ibu mereka sebagai basis aman bagi mereka untuk menjelajah lingkungan baru. Adanya orang asing menghambat penjelajahan anak, menyebabkan anak mencari sang ibu. Anak akan cemas dengan kepergian ibunya dan berusaha membuat ibu kembali dengan perilaku menangis atau mencari. Kedua Anak-anak dengan kelekatan tidak kuat-menghindar, hanya menunjukkan sedikit kepedulian atas kepergian ibunya. dalam menyambut ibunya ketika bertemu kembali, mereka secara aktif menghindari interaksi dan mengabaikan ajakan-ajakan ibu untuk berinteraksi., ketiga Anak-anak dengan kelekatan tidak kuat-resisten, cemas dengan kepergian ibunya dan berperilaku secara ambivalen ketika bertemu kembali, berusaha melakukan kontak dan berinteraksi namun sekaligus menolak dengan marah ketika diajak berinteraksi. Keempat Anak-anak dengan kelekatan tidak kuat-kacau, menunjukkan pola-pola perilaku yang bertentangan dan dampaknya merasa bingung atau takut untuk mendekati orangtuanya. Perilaku ini berkaitan dengan anak-anak yang mengalami penganiayaan atau memiliki ibu yang mengalami kecemasan berat (Upton, 2012, p. 88-89).

Berdasarkan konsep yang telah dipaparkan di atas dapat dipahami bahwa Klasifikasi attachment berdasarkan perilaku anak selama berpisah dan bertemu kembali dengan ibu atau figur dekatnya yaitu anak-anak yang memiliki attachment yang kuat dengan ibunya akan selalu membutuhkan ibunya agar selalu berada dekat dengannya, sementara anak dengan kelekatan tidak kuat-menghindar, hanya menunjukkan sedikit kepedulian atas kepergian ibunya, selanjutnya anak dengan kelekatan tidak kuat-resisten, cemas dengan kepergian ibunya dan berperilaku secara ambivalen ketika bertemu kembali dengan ibunya, sedangkan anak dengan kelekatan tidak kuat-kacau, menunjukkan perilaku takut untuk mendekati ibunya. Hal ini disebabkan karena ibunya sering melakukan penganiayaan terhadap anaknya.

Suku laut merupakan sebutan yang sangat dekat dengan suku Bajo (sea men). Suku Bajo memiliki ciri selalu mengarungi lautan dan menjadikan laut sebagai sumber kehidupan utama bagi mereka. Suku Bajo di kabupaten Wakatobi memiliki jumlah cukup banyak dan tersebar di beberapa pulau yang ada di kabupaten Wakatobi mulai dari pulau Wangi-Wangi dan Kaledupan. KB Nur Ain merupakan lembaga pendidikan anak usia dini yang ada di suku Bajo tepatnya di pulau Wangi-Wangi kabupaten Wakatobi. KB Nur Ain merupakan lembaga satuan pendidikan anak usia dini yang ada di desa Mola Selatan yang secara geografis letak desa Mola Selatan adalah sebelah utara berbatasan dengan desa Mola Samaturu, sebelah selatan berbatasan dengan desa Mola Nelayan Bahkti, sebelah timur berbatasan dengan desa Mandati III dan sebelah barat berbatasan dengan laut. Desa Mola Selatan merupakan desa yang seluruh penduduknya adalah suku Bajo, dengan mayoritas masyarakat berprofesi sebagai nelayan. Profesi sebagai nelayan di desa Mola Selatan kabupaten Wakatobi tidak hanya dilakukan oleh laki-laki saja tetapi juga dengan perempuan.

Penelitian ini memfokuskan perhatian pada kelekatan orang tua dengan anak yang ada di KB Nur Ain Mola Selatan Kabupaten Wakatobi. dengan subfokus yang akan diteliti adalah kelekatan orang tua selama berada di KB nur ain mola selatan kabupaten Wakatobi dan kelekatan orang tua selama di rumah.

\section{METODOLOGI}

Metode penelitian yang digunakan dalam penelitian ini adalah kualitatif. Penggunaan pendekatan kualitatif digunakan untuk memperoleh pemahaman mendalam tentang kelekatan anak usia dini di suku laut yang berada di desa Mola Selatan kabupaten Wakatobi. Selanjutnya, dideskripsikan hasil temuan dan pemahaman dalam bentuk deskripsi dengan bahasa yang tepat dan sistematis berdasarkan fakta-fakta yang ada dalam penelitian. 
Pendekatan kualitatif memiliki beberapa strategi yang spesifik, yang dalam penelitian ini menggunakan studi fenomenologis. Creswell menyatakan bahwa studi fenomenologis memberikan pemaknaan umum dari sejumlah individu terhadap berbagai pengalaman hidup terkait konsep dan fenomena (Creswell, 2015, p. 105). Penelitian ini memahami permasalahan secara mendalam yaitu kelekatan orang tua dengan anak selama berada di lembaga pendidikan anak usia dini maupun kelekatan anak dengan orang tua selama berada di rumah. Studi fenomenologis ini membantu peneliti menemukan esensi dari kelekatan anak terhadap figur dekatnya yaitu ibu selama berada di sekolah dan di rumah.

Penelitian ini dilakukan di suku laut yang ada di kabupaten wakatobi tepatnya di desa mola selatan kabupaten wakatobi tepatnya di kelompok bermain (KB) Nur Ain Mola Selatan, dengan waktu pelaksanaan dari bulan Juli sampai September 2019. Adapun subjek penelitian yaitu anak kelompok B KB Nur Ain Mola Selatan dengan figur dekatnya yaitu Ibu, Guru dan Kepala Sekolah KB Nur Ain Mola Selatan dan kepala Desa Mola Selatan Kabupaten Wakatobi yang ditentukan oleh peneliti secara purposive sampling. Adapun anak kelompok B KB Nur Ain Mola Selatan dengan Figur dekatnya yaitu berjumlah 5 orang. 2 orang guru yang ada di KB Nur Ain Mola Selatan, 1 Kepala KB Nur Ain Mola Selatan serta Kepala Desa Mola Selatan sehingga data yang diperoleh akurat.

Teknik pengumpulan data yang peneliti gunakan adalah wawancara, observasi dan studi dokumentasi. Adapun teknik analisis data dalam penelitian ini menggunakan interactive model dari Miles dan Huberman dengan langkah-langkah analisis data yaitu reduksi data, penyajian data, penarikan kesimpulan dan verifikasi. Teknik pemeriksaan keabsahan data yang digunakan adalah teknik credibility (derajat kepercayaan) yakni, triangulasi member check.

\section{HASIL DAN PEMBAHASAN}

Data penelitian diambil dengan menggunakan teknik observasi, wawancara dan dokumentasi terhadap kelekatan orang tua dengan anak usia dini di suku laut yang menjadi subjek penelitian.

Berdasarkan hasil observasi dan wawancara kepada orang tua, guru dan kepala KB nur ain yang ada di desa mola selatan kabupaten wakatobi diperoleh temuan hasil penelitian bahwa secara umum kelekatan anak usia dini dengan figur dekatnya atau ibunya di suku laut pada kategori kelekatan yang kuat. Hal ini dapat kita temukan seperti yang terlihat dalam dokumentasi berikut ini;

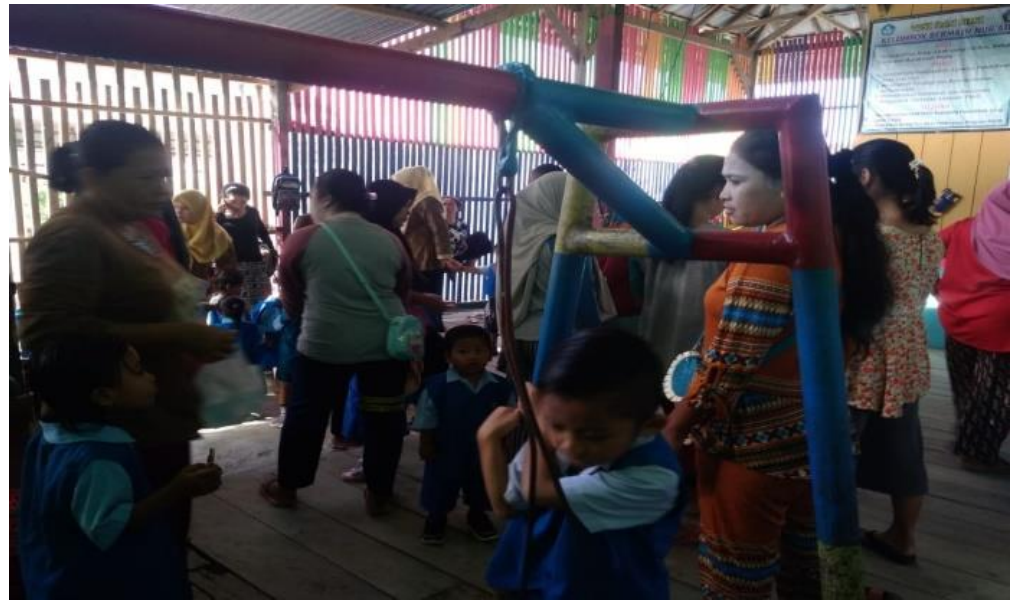

Gambar 2. Suasana Orang tua dan anak saat lembaga PAUD

Berdasarkan data yang diperoleh dari dokumentasi kegiatan di lembaga pendidikan anak usia dini di suku laut desa mola selatan kabupaten wakatobi dapat diperoleh informasi bahwa kelekatan anak dengan figur dekatnya yaitu ibunya pada kategori kelekatan yang kuat, yaitu setiap hari di lembaga pendidikan anak usia dini selalu bersama mulai dari pada 
saat datang diantar oleh ibunya tidak hanya tidak hanya sampai depan sekolah atau depan kelas tetapi diantar sampai di dalam kelas, sampai saat pulang ibunya selalu berada di dekatnya. Seperti data dari dokumentasi di bawah ini;

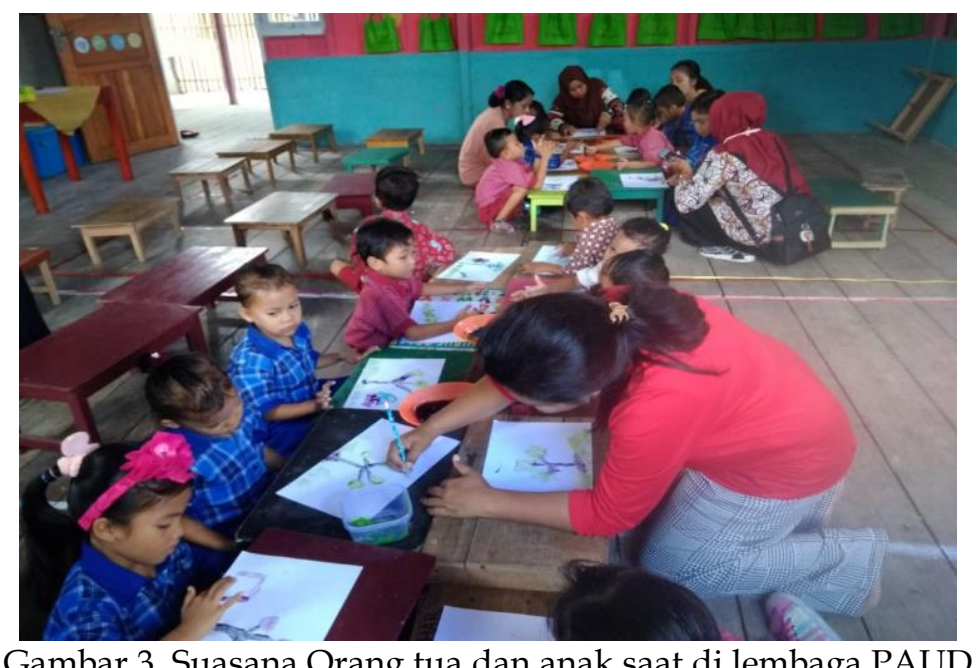

Kelekatan figur dekat atau ibu dengan anak usia dini suku laut di desa mola selatan kabupaten wakatobi pada umumnya memiliki kategori yang sama antara satu ibu dengan ibu yang lain yaitu selalu bersama anak dalam melakukan aktivitas. sebagaimana keterangan yang disampaikan oleh Sri Martini mengemukakan bahwa kedekatan antara semua ibu dengan anaknya yang masih usia dini di suku laut yang berada di desa mola selatan kabupaten wakatobi sama antara ibu yang satu dengan lainnya.

Kalian bisa melihat sendiri bagaimana kedekatan antara ibu dengan anak-anaknya di sini. Semua ibu selalu mengantar anaknya dan tidak langsung pulang setelah tiba di sekolah tetapi tunggu anak sampai pulang tapi tunggu-nya masuk dalam kelas duduk di dekat anaknya (wawancana dengan Sri Martini, Kepala KB Nur Ain desa mola selatan pada 28 Agustus 2019).

Kelekatan anak dengan ibunya di suku laut desa mola selatan kabupaten wakatobi juga dijelaskan oleh Rosnia bahwa orang tua dan anak di suku laut desa mola selatan selalu bersama utamanya pada saat anak ke sekolah di KB Nur Ain mola selatan, dan ini telah terjadi selama bertahun-tahun atau selama sekolah ini didirikan yaitu perilaku kedekatan anak dengan ibunya selalu bersama ke sekolah.

Anak-anak di sini selalu diantar ibunya kalau datang ke sekolah, setelah diantar ibunya tidak bisa pulang karena kalau pulang maka anaknya juga ikut pulang dan ini sebagian besar atau hanya satu dua anak yang tidak begitu (wawancana dengan Rosnia, Guru di lembaga PAUD yang ada di desa mola selatan pada 30 Agustus 2019)

Hasil observasi yang dilakukan oleh peneliti menemukan bahwa kedekatan anak usia 5-6 tahun di suku laut desa mola selatan kabupaten wakatobi dengan ibunya berada kelekatan yang kuat yaitu selalu bersama, anak akan berada di samping ibunya pada saat anak itu berada di sekolah namun anak akan melakukan aktivitas bermain bersama teman ketika di rumah tanpa pengawasan ibunya atau kehadiran ibu di dekat anak tidak akan dianggap atau bahkan akan dianggap mengganggu aktivitas bermain bersama temannya. Tetapi kalau ibunya berada di tempat yang tidak dilihat maka akan dicari oleh anak.

Nuhardin menjelaskan bahwa anak usia dini suku laut di desa mola selatan kabupaten wakatobi memiliki kemandirian dalam melakukan sesuatu, berenang layaknya orang dewasa telah bisa dilakukan, memancing ikan, duduk di atas perahu dan aktivitas- 
aktivitas yang lain tetapi kalau untuk sekolah anak usia dini suku laut desa mola selatan butuh figur dekatnya untuk melakukan aktivitas di lembaga-lembaga pendidikan anak usia dini.

Anak di sini melakukan kegiatannya sendiri mulai dari berenang di laut, mencari ikan, ikut orang tua bawa perahu jual ikan di pasar dan lain sebagainya. Kalau di sekolah mereka harus ada ibunya atau orang tuanya karena mereka tidak mau kalau tidak ditemani (Wawancara dengan Nuhardin, Kepala Desa Mola Selatan 28 juli 2019).

Perilaku kelekatan anak usia 5-6 tahun di KB Nur Ain Mola Selatan Kabupaten Wakatobi juga dijelaskan oleh Ibu Rimawati yang mengemukakan bahwa selama anak berapa di KB Nur Ain Mola Selatan akan selalu didampingi oleh ibunya, mulai sejak masuk untuk bersekolah sampai tamat. Kelekatan anak dengan ibu di rumah tidak seperti di sekolah, anak membutuhkan ibunya untuk berada di samping atau berada tidak di samping tapi masih terlihat oleh anak selama anak melakukan aktivitasnya selama di rumah.

Kami selalu bersama, saya dan alyana selalu bersama. Kalau di sekolah saya juga masuk ke kelas karena kalau tidak dia pulang setelah saya pulang. Tapi kalau di rumah yang penting dia lihat saya waktu main-main dengan teman-temannya (wawancana dengan Ibu Rimawati, orang tua anak usia 5-6 tahun peserta didik di KB Nur Ain Mola Selatan, pada 26 Agustus 2019).

Berdasarkan temuan fakta lapangan yang telah dikemukakan oleh peneliti di atas tentang perilaku kelekatan anak usia 5-6 tahun suku laut yang berada di KB Nur Ain Mola Selatan Kabupaten Wakatobi di peroleh pemahaman bahwa kelekatan sebagai hubungan emosional yang membawa kenyamanan, keamanan dan menenangkan antara ibu dengan anak serta salah satu akan merasa kehilangan jika yang lain tidak berada di dekatnya berada pada tipe kelekatan yang kuat yaitu ibu dengan anak selalu bersama mulai dari mengantar ke sekolah, menemani walaupun berada di dalam kelas dan menunggu sampai anak pulang ke rumah bersama ibunya. Sementara kelekatan anak usia 5-6 tahun suku laut dengan ibu saat berada di rumah adalah tipe kelekatan yang tidak kuat yaitu anak tidak terlalu membutuhkan sosok figur dekatnya atau ibunya untuk selalu berada di sampingnya cukup sosok figur dekat itu dilihat oleh anak saat melakukan aktivitasnya walaupun jarak figur dekat itu agak berjauhan dengan anak yang bersangkutan. Sebagaimana yang diungkapkan oleh Adisti bahwa aktivitas anak saat berada di rumah tidak seperti di sekolah, aktivitas yang anak lakukan di rumah secara mandiri tidak terlalu membutuhkan figur dekatnya atau ibunya untuk selalu berada di sampingnya walaupun anak harus tetap melihat ibunya saat melakukan aktivitas bermain dengan reka-rekannya.

Di rumah tidak seperti di sekolah, di rumah dia bermain dengan teman-temannya seperti biasa, tidak harus saya bantu atau saya ada di sampingnya cukup dia lihat saya ada dimana (wawancana dengan Ibu Adisti, orang tua anak usia 5-6 tahun peserta didik di KB Nur Ain Mola Selatan, pada 27 Agustus 2019).

Berdasarkan fakta-fakta lapangan yang ditemukan dalam penelitian tentang kelekatan anak usia 5-6 tahun suku laut desa mola selatan kabupaten wakatobi, dapat dijelaskan bahwa kelekatan antara anak dengan figur dekatnya yaitu ibu saat berada lingkungan pendidikan yaitu di KB Nur Ain Mola Selatan kelekatan yang tampak berada pada kategori kelekatan yang kuat yaitu anak dengan figur dekatnya selalu bersama sejak mengantar anak ke sekolah, masuk ke dalam kelas untuk berada di samping anaknya belajar sampai pulang ke rumah setelah belajar. Sebagaimana yang diungkapkan oleh Upton yang menyatakan bahwa anak dengan kelekatan kuat, akan menggunakan ibu mereka sebagai basis aman bagi mereka untuk menjelajah lingkungan baru atau melakukan aktivitas kesehariannya. Adanya orang asing atau dengan tidak dilihatnya figur dekat di samping 
anak akan menghambat penjelajahan atau aktivitas anak sehingga menyebabkan anak akan mencari sosok figur dekatnya yaitu sang ibu. Anak akan cemas dengan kepergian ibunya atau anak akan berusaha untuk mencari ibunya jika anak tidak melihat sosok ibunya dan berusaha membuat ibu kembali dengan perilaku menangis atau mencari. (Upton, 2012, p. 88). Kelekatan juga memiliki dampak pada motivasi belajar anak sebagaimana yang diungkapkan oleh Isroiyah yang menyatakan bahwa kelekatan memiliki pengaruh terhadap motivasi belajar anak (Isroiyah, 2016, p. 1). Hasil penelitian yang lain juga menyimpulkan bahwa semakin anak memiliki kelekatan dengan orang tua maka anak akan memiliki nilainilai karakter dasar (Sari, Hasnah R., Nurdin, Said dan Husen, 2017, p. 39).

Kelekatan anak usia 5-6 tahun suku laut desa mola selatan kabupaten wakatobi dengan ibunya saat di lingkungan sekolah, dapat dipahami sebagai kelekatan yang berdampak dari keinginan atau motivasi anak untuk belajar dengan ditemani oleh figur dekatnya yaitu ibu sampai di dalam kelas. Kelekatan anak dengan figur dekatnya akan terbentuk dari interaksi antara keduanya, Santoso dan Batubara menyatakan bahwa kelekatan antara ibu dan anak terbentuk dari interaksi kerjasama keduanya dalam menjalankan tugas-tugasnya di lingkungan sosialnya masing-masing (Santoso, Meilanny B., dan Batubara, 2017, p. 61). Kelekatan yang aman memiliki hubungan signifikan dan positif dengan kematangan emosi anak (Natalia, Christian dan Lestari, 2015, p. 78). Larasati dan Desiningrum juga menyatakan bahwa anak dengan kelekatan yang aman dengan ibunya akan memiliki regulasi emosi (Larasati, Nurhayati Isti'anah dan Desiningrum, 2017, p. 132).

Selanjutnya juga ditemukan fakta-fakta lapangan dalam penelitian tentang kelekatan anak usia 5-6 tahun suku laut desa mola selatan kabupaten wakatobi, dapat dijelaskan bahwa kelekatan antara anak dengan figur dekatnya yaitu ibu saat berada laur lingkungan pendidikan anak usia dini atau saat berada di rumah. Kelekatan yang tampak berada pada kategori kelekatan yang tidak kuat yaitu anak dengan figur dekatnya tidak harus selalu bersama, anak melakukan aktivitasnya secara baik dan cukup mandiri, keberadaan figur dekatnya cukup dilihat oleh anak dengan jarak yang berjauhan tidak menjadi masalah atau anak tidak akan membutuhkan figur dekatnya untuk selalu di sampingnya atau dekatnya. Aktivitas bermain bersama temannya dilakukan dengan tanpa bantuan sosok figur dekatnya. Anak akan membutuhkan figur dekatnya jika setelah melakukan aktivitasnya sosok figur dekatnya atau ibunya tidak dilihatnya. Upton menyatakan bahwa kelekatan anak pada kategori yang tidak kuat terdapat beberapa tipe yaitu anak dengan kelekatan yang tidak kuat-menghindar, anak dengan kelekatan yang tidak kuat-resisten dan anak dengan kelekatan yang tidak kuat-kacau (Upton, 2012, p. 88-89). Anak yang memiliki kelekatan dengan figur dekatnya pada kategori kelekatan tidak kuat-menghindar memiliki ciri antara lain tidak terlalu peduli dengan kepergian figur dekatnya atau hanya menunjukkan sedikit kepedulian atas kepergian ibunya dan setelah bertemu kembali dengan figur dekatnya akan di sambut karena telah bertemu kembali, anak pada tipe kelekatan ini secara aktif menghindari interaksi dengan figur dekatnya dan mengabaikan ajakan-ajakan ibu untuk berinteraksi untuk beberapa saat. Sementara Anak dengan kelekatan tidak kuat-resisten memiliki ciri kelekatan yaitu cemas dengan kepergian figur dekatnya atau ibunya dan akan berperilaku secara ambivalen saat bertemu kembali dengan sosok figur dekatnya, anak pada kategori kelekatan ini juga akan berusaha melakukan kontak dan berinteraksi dengan sosok figur dekatnya namun di saat yang sama juga menolak dengan marah ketika diajak berinteraksi. Sedangkan anak dengan kelekatan yang tidak kuat-kacau memiliki ciri yaitu menunjukkan pola-pola perilaku yang bertentangan dan dampaknya merasa bingung atau takut untuk mendekati orangtuanya. Perilaku ini berkaitan dengan anak-anak yang mengalami penganiayaan atau memiliki ibu yang mengalami kecemasan berat.

Kelekatan anak usia 5-6 tahun suku laut desa mola selatan kabupaten wakatobi dengan ibunya saat di berada di rumah, dapat dipahami sebagai kelekatan yang berada pada kategori tidak kuat tetapi bukan pada kategori kelekatan tidak kuat-menghindar, 
resisten atau kacau seperti yang dijelaskan sebelumnya. Kelekatan anak saat berada di rumah tidak sekuat seperti halnya kelekatan anak saat berada di lembaga pendidikan anak usia dini. Anak tetap membutuhkan sosok figur dekatnya atau ibunya untuk senantiasa dilihatnya saat anak melakukan aktivitas kesehariannya dan anak akan langsung mencari sosok figur dekatnya saat anak tidak lagi melihat figur dekatnya. Temuan penelitian memperkuat hasil penelitian yang dilakukan oleh peneliti sebelumnya yang menyatakan bahwa kelekatan anak dengan sosok figur dekatnya atau ibunya memiliki perbedaan antara di rumah dengan saat berada di lembaga pendidikan (Hewi, 2015, p. 90). Perbedaan kelekatan anak dengan figur dekatnya atau ibunya, yaitu pada saat anak berada di rumah dengan saat anak berada di lingkungan sekolah atau lembaga pendidikan anak usia dini terjadi karena keinginan masyarakat bajo untuk menyekolahkan anak-anak mereka sangat tinggi. Tahara mengemukakan bahwa ada stereotip yang disematkan oleh suku lain di Wakatobi pada masyarakat bajo yang dianggap sebagai orang-orang bodoh dan kotor bahkan sebagai perampok di laut (Tahara, 2013, p. 55). Hal ini ingin diubah oleh suku Bajo di Wakatobi melalui pendidikan yaitu kebangkitan indentitas melalui pendidikan.

\section{SIMPULAN}

Kelekatan anak usia 5-6 tahun suku laut desa mola selatan kabupaten Wakatobi pada berada pada ketegori kelekatan yang kuat, yaitu anak akan selalu bersama ibunya, dalam melakukan aktivitas belajar di lembaga pendidikan anak usia dini anak sangat membutuhkan kehadiran ibunya untuk selalu berada di sampingnya, melakukan sesuatu dengan bantuan atau pengawasan dari figur dekatnya yaitu ibu. Kelekatan anak memiliki perbedaan pada saat anak berada di rumah atau bukan di lingkungan sekolah dengan saat anak berada di lingkungan sekolah atau lembaga pendidikan anak usia dini. Hal ini karena keinginan suku laut (suku Bajo) untuk menyekolahkan anak-anak mereka sangat tinggi.

\section{UCAPAN TERIMAKASIH}

Ucapan terima kasih peneliti sampaikan kepada semua pihak yang telah membantu penelitian ini sampai selesai utamanya kepala desa Mola Selatan, kepala lembaga PAUD desa Mola Selatan serta dewan guru dan orang tua peserta didik yang telah bersedia untuk diwawancarai serta adik-adik mahasiswa KKN berbasis riset IAIN Kendari yang banyak membantu pengambilan data.

\section{DAFTAR PUSTAKA}

Anapratiwi, D., Handayani, S.L.D., dan Kurniawati, Y. (2013). Hubungan antara Kelekatan Anak pada Ibu dengan Kemampuan Sosialisasi Anak Usia 4-5 tahun (studi pada RA Sinar Pelangi dan RA Al Iman Kecamatan Gunungpati Semarang. Indonesian Journal of Early Childhood Education Studies, 2(2), 27.

Aulya Purnama, R., \& Wahyuni, S. (2018). Kelekatan (Attachment) pada Ibu dan Ayah Dengan Kompetensi Sosial pada Remaja. Jurnal Psikologi, 13(1), 30. https:// doi.org/10.24014/jp.v13i1.2762

Bowlby, J. (1984). Attachment and Loss (2nd ed.). New York: Tavistock Institute of Human Relations; NY Basic Books.

Cenceng. (2015). Perilaku Kelekatan pada Anak Usia Dini (Perspektif John Bowlby). Lentera, $\operatorname{IXX}(2), 141-153$.

Crain, W. (2007). Teori Perkembangan Konsep dan Aplikasi (Y. Santoso, Ed.). Yogyakarta: Pustaka Pelajar.

Creswell, J. W. (2015). Research Design Pendekatan Kualitatif, Kuantitatif, dan Mixed. Yogyakarta: Pustaka Pelajar.

Hewi, L. (2015). Kemandirian Usia Dini di Suku Bajo. Jurnal Pendidikan Usia Dini, 9(1), 75-92. Isroiyah, D. (2016). Pengaruh Kelekatan dengan Orang Tua terhadap Motivasi Belajar Anak 
Melalui Self-Efficacy Siswa di MTs. Al-Ittihadiyah Canggu Badas Kediri. Didaktika Religia, 4(1), 29-54. https:/ / doi.org/10.30762/didaktika.v4.i1.p29-54.2016

Izzah, I. (2017). Peranan Gaya Kelekatan Kepada Orangtua dengan Harga Diri pada Remaja. Jurnal Sosiologi Reflektif, 11(2), 125. https:/ / doi.org/10.14421/jsr.v11i2.1355

Kurnia Illahi, S. P., \& Akmal, S. Z. (2018). Hubungan Kelekatan dengan Teman Sebaya dan Kecerdasan Emosi pada Remaja yang Tinggal di Panti Asuhan. Psikohumaniora: Jurnal Penelitian Psikologi, 2(2), 171. https:/ / doi.org/10.21580/pjpp.v2i2.1854

Larasati, Nurhayati Isti'anah dan Desiningrum, D. R. (2017). Hubungan Antara Kelekatan Aman dengan Ibu dan Regulasi Emosi Siswa Kelas X SMA Negeri 3 Salatiga. Jurnal Empati, 7(3), 127-133.

Natalia, C., \& Lestari, M. D. (2015). Hubungan Antara Kelekatan Aman pada Orang Tua dengan Kematangan Emosi Remaja Akhir di Denpasar. Jurnal Psikologi Udayana, 2(1), 78-88. https://doi.org/10.24843/JPU.2015.v02.i01.p08

Nauli, V. A., Karnadi, K., \& Meilani, S. M. (2019). Peran Ibu Pedagang Pasar 24 Jam Terhadap Perkembangan Moral Anak (Penelitian Studi Kasus di Kota Bekasi). Jurnal Obsesi: Jurnal Pendidikan Anak Usia Dini, 3(1), 241. https://doi.org/10.31004/obsesi.v3i1.179

Nurhayati, H. (2015). Hubungan Kelekatan Aman (Secure Attachment) Anak pada Orangtua dengan Kemandirian Anak Kelompok B TK PKK 37 Dodogan Jatimulyo Dlingo Bantul. Jurnal Pendidikan Guru Pendidikan Anak Usia Dini, 9(tahun ke-4), 1.

Oates, M. W. J. (2007). Attachment relationships. United Kingdom: Milton Keynes.

Perry, B. D. (2013). Bonding and Attachment.

Prasetyaningrum, S., \& Rahma, F. O. (2016). Kepribadian terhadap Gaya Kelekatan dalam Hubungan Persahabatan. Psympathic: Jurnal Ilmiah Psikologi, 2(2), 153-168. https://doi.org/10.15575/psy.v2i2.456

Robbiyah, R., Ekasari, D., \& Witarsa, R. (2018). Pengaruh Pola Asuh Ibu terhadap Kecerdasan Sosial Anak Usia Dini di TK Kenanga Kabupaten Bandung Barat. Jurnal Obsesi: Jurnal Pendidikan Anak Usia Dini, 2(1), 74. https://doi.org/10.31004/obsesi.v2i1.10

Santoso, Meilanny B., dan Batubara, M. (2017). Kelekatan Antara Ibu dan Anak Usia Sekolah (Studi pada Ibu Sebagai Orang Tua Siswa Kelas 1 SDN Hanjuang Samijaya). Empati Jurnal Ilmu Kesejahteraan Sosial, 6(1), 61.

Sari, Hasnah R., Nurdin, Said dan Husen, M. (2017). Hubungan Kelekatan Orangtua pada Anak dengan Nilai-nilai Karakter Dasar Siswa SMP Negeri 3 Kota Banda Aceh. Jurnal Ilmiah Mahasiswa Bimbingan Dan Konseling, 2(1), 39-47.

Scott, E. (2011). Briefing on attachment. Public Health Adviser, Evidence for Action, NHS Health Scotland, p. 1.

Tahara, T. (2014). Kebangkitan Identitas Orang Bajo di Kepulauan Wakatobi. Antropologi Indonesia, 34(1), 41-57. https:// doi.org/10.7454/ai.v34i1.3196

Upton, P. (2012). Psikologi Perkembangan (N. F. Widuri, Ed.). Jakarta: Erlangga.

Vega, A. De, Hapidin, H., \& Karnadi, K. (2019). Pengaruh Pola Asuh dan Kekerasan Verbal terhadap Kepercayaan Diri (Self-Confidence). Jurnal Obsesi : Jurnal Pendidikan Anak Usia Dini, 3(2), 433. https://doi.org/10.31004/obsesi.v3i2.227

Wahyuni, Sri dan Asra, Y. K. (2014). Kecenderungan Anak Menjadi Pelaku dan Korban Bullying Ditinjau dari Kualitas Kelekatan Dengan Ibu Yang Bekerja. Marwah, XIII(1), 1-20.

Weingarten, C. P., \& Chisholm, J. S. (2009). Attachment and Cooperation in Religious Groups. Current Anthropology, 50(6), 759-785. https:/ / doi.org/10.1086/605767 